\begin{tabular}{ccc}
\hline Mournals & MARKETING AND BRANDING & $\begin{array}{c}\text { INDUSTRIAL } \\
\text { RESEARCH } \\
\text { MANAGEMENT } \\
\text { AIMI }\end{array}$ \\
\hline \hline
\end{tabular}

\title{
The study of issuance of stocks in venture companies listed in Tehran Stock Exchange
}

\author{
Ali Amiri ${ }^{1}$, Hamid Ravanpaknodezh ${ }^{2}$, Akbar Jelodari ${ }^{3 *}$ \\ ${ }^{1} \mathrm{PhD}$ in Accounting, Faculty member of Human Sciences, Department of Accounting, Bandar Abbas Branch, \\ Islamic Azad University, Hormozgan, Iran \\ ${ }^{2} \mathrm{PhD}$ in Accounting, faculty member of Qeshm Institute of Higher Education, Hormozgan, Iran \\ ${ }^{3}$ MSc in Financial Management, Qeshm Institute of Higher Education, Hormozgan, Iran
}

Keywords:

Financing, Issuance of Stocks, Capital Market, Tehran Stock Exchange

Correspondence: akbar.jelodari@gmail.com

\begin{abstract}
In order to implement the profitable projects, achieve the maximum efficiency, and increase their shareholders, companies may use different types of financial resources in different ways. The ability of companies to identify the internal and external resources for providing capital and financial programs is considered as one of the main factors that affects on the growth and development of the companies. Financing resources and their usage volume are factors that affect on the companies' operating performance. In this regard, companies and economic institutions can be financially provided from both inside and outside. Companies can issue and sell new common stocks to investors to provide their required financial resources. This study was conducted to investigate the issuance of stocks as one of resources of financing in the companies. Statistical population of this study was active listed companies in Tehran Stock Exchange. The sample of study was selected among listed companies raising capital through applying stage random sampling and simple random sampling. Sampling was conducted during the period 2008-20013 and finally the sample size including 40 companies were chosen using a Cochran formula. To analyze the obtained information, t-test and correlation coefficient were used. Although the results of the study revealed that there was no significant difference between the internal sources of financing and the issuance of stocks among the studied companies, there is a significant relationship between companies' issuance of stocks and their size. Companies increase the use of retained earnings and stocks for financing through expanding the size of companies. Also, due to the existence of relationship between financing and the fixed assets of the companies through issuing the stocks of companies, no statistically significant relationship were observed between financing and companies' profitability. Finally, there was no significant relationship between financing and future stock returns through the issuance of stocks.
\end{abstract}


Choosing the method of financing is considered as one of the main concerns of managers in every decision-making area to determine the company's market value and maximize shareholders' wealth. The survival and continuance of the companies' activities require financial resources which their provision often accompanied by spreading limitation. To continue the process of attracting resources, their usages should provide an appropriate share of market value for the company as well as suppliers of funds. Economic institutions especially those which are active in the industrial sectors require macro-level capitals to survive and continue their productive activities as well as developing their activities. The performance of these institutions is highly dependent on the financial markets to meet their capital requirements. The role of these markets is to provide funds for institutions and companies. One of the main points of interest in financial/economic institutions is the methods and levels of financing. Creation and development of companies require considerable financing which seems to be beyond the limit of founders' ability. Capital market enables companies to provide considerable financial resources through offering and selling securities. In other words, capital market acts as a channel to transfer resources from savers to consumers of financial resources and plays a strategic role in the economy of countries through providing the needed capital of economic institutions and efficient allocation of resources. The managers of companies attempt to survive and grow the organizations by using obtained resources. However, conditions such as intense competition, economic, political, and financial crises, and legal and ownership requirements have prompted companies to demand more resources and sometime reinvest them within economic units which belong to their owners. Financing becomes a common practice in large companies and companies' management has various sources of financing at their disposal to provide funds for capital expenditure and companies financial operations. Financing can be done through issuance of stocks or debt securities which their difference is evident. Some theories have addressed the reasons why companies choose special financing methods and how such choices will be reflected in the company's past and future performance. A vast collection of research has examined the role of underlying factors, the effects of financing, the relationship between financing and debt through the issuance of debt, stocks, and profit, and future free cash flows (Casser, 2005).

\section{Main Reasons of Financing}

The motivation of managers of providing financial needs of companies can be categorized into three major reasons including debt repayment, investment in new projects, and compensation of operating cash flow shortage (Healy \& Krishna, 1990). Furthermore, financing resources in the country can be divided into two main types, namely financial resources without cost and with cost. Financial resources without cost include deposit from customers, trade creditors, dividends payable account, and expenses payable. The finance literature documents show that financial resources with cost consist of two categories namely internal resources (retained earnings) external resources (short-term and long-term bank loans and issuing new shares) (Rezaul \& Roosenboom, 2003; Richardson \& Richard, 2003). 


\section{Different Types of Financing Methods}

In a general classification, companies' financing methods can be divided into two main categories including short-term financing and long-term financing. Short-term financing refers to a type of financial provision which is repaid during a year. Three main sources of short-term financing are trade credits, getting bank loans from commercial banks, issuing of commercial paper. On the other hand, long-term financing services are obtained from longterm source. In other words, monthly loan repayment will take more than a year. The main sources of long-term financing for companies are the issuance of corporate bond, preferred stock, and common stock and financing from retained earnings which is also called internal financing. Three primary sources of long-term financing services and the sources of shortterm financing services are known as external financing because these resources describe the funds that companies obtain from outside of the company. In this study, the issuance of stocks is considered external. The key difference between debts and stocks is that in stock mode the absorbed financial resources is considered as companies' long-term resources and the companies are not obliged to repay them. Another important difference is that interest on debts is attributed to tax savings while the dividend payments to common stock shareholders is no subject to tax saving. Generally, companies list and release debt securities and capital securities. The main question is that how the companies attempt to provide financial resources to have maximum positive impact on companies' profits and total shareholder returns? Several factors can affect companies' financing structure including the nature of activities, assets, and industry types; for example, the nature of the activities may be such that the input cash flow is easily provided. In such situation, using debt instead of share such as debt financing is cheaper than stock and increases the profits of company. As company managers increase their debts, the return on equity is also improved. Improving return on equity occurs through clearing financial costs and tax savings from debts (Bigdellou, 2004). One of the main goals of financial management is to maximize the shareholders' wealth. To achieve this end, financial managers try to find ways for providing financial resources. Financial managers' main responsibilities or duties are making decision related to the financing, making investment, and profit sharing (Van Horn, 1995).

\section{Pecking Order Theory of Finance}

Pecking order theory of finance is popularized by Myers and Majluf (1984) which explains the inverse relationship between profitability and debt ratios. This theory maintains that companies adhere to a hierarchy of financing sources and prefer internal financing sources when they are available, they adapt their target dividend payout ratios to avoid sudden changes in dividends with respect to their investment opportunities, Selecting sticky dividend policies for dealing with unexpected changes in profits and investment opportunities. It means that sometimes caused internal cash flows is more than capital expenditures and sometimes is less than the cost of capital. If cash flow is more than the cost of capital, the company will pay back its debts. If cash flows are less than the cost of capital, the company first draws down its bank account balance or its sale marketable securities rather than reducing dividends (short-term). If external financing is needed, companies first issue the 
most reliable securities. And finally, companies first use debt, then if possible, hybrid securities such as convertible bond (Myers, 1984).

Economic or financial institutions commonly use medium-term and long-term financing method $s$ to offer the securities to the public. Many economic institutions which us the securities rather than common or preferred stocks and bonds usually prefer to use specialized services of financial institutions and investment banks. Although financial institutions or investment banks practically undertake the activities relating to the buying and selling of securities most of the time, in some special cases, economic institutions directly sell the issuance securities to investors and therefore the term of direct issuance of securities is commonly used. Direct issuance of securities is usually done by in the issuance of common stock. Sometimes, economic institutions use the financial institutions and investment banks services to sell their securities which are cheaper and more convenient than the direct sale of these securities. Financial institutions and investment banks are specialists in the sale of securities that are issued recently and usually are familiar with demands of potential investors and due to the characteristics of each item of securities, contact with interested investors. The profit of financial institutions and investment banks has been provided from the difference between the securities' purchase and sell rates. The main point in the process of acquiring and managing financial resources is that any financier, regardless of its financing methods, should pay interest for their primary and secondary expenses. This payments surplus is called the cost of capital; therefore, capital costs or financing refers to the minimum rate of return that the company should acquire to provide the selected investors' or sponsors' return in the company.

\section{Common Stocks}

Stocks are considered to be part of the companies' capital and classified as financial assets. Stocks also indicate the ownership of a person in a company. Ordinary shareholders are the owners of companies and other assets belong to them especially at the time of dissolution when other receivables including preferred stocks should be paid. After preferred stock and corporate bonds, common stocks have the highest risk for its holder. All common shareholders have some rights including the rights of transfer their shares, limited liability, management of the company, and participation in share capital increase.

First, shareholders have right to sell their shares to other people. Stocks are divided into two categories including named and unnamed ones. In Tehran Stock Exchange, common named stocks which belong to the public companies can be accepted and traded. Second, shareholders' liability is limited to their contribution. This means that if the company went bankrupt, its assets should be sold to pay to its creditors. If available assets are not enough to pay debts, common stock owners are not responsible for the differences. Third, each shareholder has right to interfere in the company's management through participation in general assemblies in which strategic decisions are taken. Decisions are made by the majority of votes and each shareholder according to the number of stocks has right to vote. To select the members of the board of directors, cumulative voting is used. In this kind of voting, the right of each shareholder should be calculated by multiplying the number of stocks to the number of people who are elected as the member of the board of directors and can assign all 
their votes to one, two or more people. This process provides the conditions in which the minority of shareholders can elect the members of board of directors in accordance with their minority. Equation 1 can help to determine the number of shares required to elect the member of the board of directors. In this equation, $r$ shows the number of stocks that can be selected by $d$ member of the board of directors, $b$ stands for the number of board members which are going elected, and $s$ refers to the number of present at the meeting stocks which have voting rights.

(1) $\mathrm{r}=\frac{\mathrm{d} \times s}{\mathrm{~b}+1} \quad+1$

The final right is the right of participation in the capital increase because one way of financing each company is raising capital. Raising capital may be done through nominal price increase of the shares or issuing new shares. Normally, the listed companies on the stock exchange raise their capital through issuing new shares through following three-step process. The first step refers to the approval of the capital increase in an extraordinary general assembly and determining of the type of sailing and pricing of new shares. The second step points to the shareholders who were shareholders before the date of the extraordinary general assembly and have priority in the purchase of new shares in proportion to the percentage of ownership and therefore can purchase new stocks. The final step states that since some shareholders may not participate in the raising capital, the company should issue the priority and free of charge certificate to each shareholder in proportion to the number of shares that will be purchased. Each shareholder can get new stock up to determined date with the presentation of certificates of priority or can sell any number of priority certificates in stock exchange market.

\section{Advantages and Disadvantages of Issuing Common Stocks}

Issuing the common stocks has a number of advantages and disadvantages. First, issuance of common stocks is one of financing methods. Due to not having maturity date, common stocks are considered as one of permanent sources of financing. Second, common stocks does not a fixed amount; therefore, the through by changing the ratio of debt to the rights of shareholders. Third, issuing the new stocks does not require to pay a fixed dividend; therefore, issuance of common stocks does not increase the risks of bankruptcy and corporate financial risks. Finally, the companies that are members of the stock exchange can easily increase their capital through presenting the priority certificate any shareholders who have no tendency to raise capital can sell his priority.

On the other hand, there are some serious disadvantages under which the issuance of common stocks suffers. One of them is the cost of equity capital which is higher than other financing sources. This means, the common stock is an expensive source of financing. Furthermore, the payment of interest expense is a reasonable tax cost which increases tax savings while this type of savings is not true in the case of common stocks. Finally, if a shareholder does not want to use his right of priority, the percentage of his ownership reduces and the control of the company will be changed. Moreover, if the companies cannot obtain intended profits equal to their achieved efficiency ratio from new investments, this will reduce earnings of per share and would have an overall negative effect on stock prices. 


\section{Value of Common Stocks}

There are different types of stock value including nominal value, book value, liquidation value, trading or market value, and intrinsic value. Nominal value refers to the price which is written on the stock and equals to capital divided by number of issued shares. Book value pointed to the shareholders' equity divided by the number of stocks and liquidation value states that if a company is liquidated, how much should pay per share. Liquidation value is calculated through equation 2 .

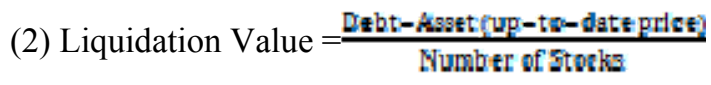

Trading or market value refers to the price at which the stock to be traded and is determined by supply and demand. Finally, intrinsic value of a share or the actual price of share is the most important factor in making investment decisions in the stock exchange market. The value of any asset is the present value of the existing earnings from that asset. The incomes holding from shares include the dividends which shareholders receive each year and the price of the sale for per share in the year $n$.

\section{The Review of Literature}

Incorrect pricing theory indicates that the active economic units attempt to release the securities, when their shares become overvalue (Loughran \& Ritter, 2000). According to the wealth transfer theory (Eberhart \& Siddique, 2002), the efficient securities issuance will lead to the transfer of wealth to the beneficiaries. Common point between this hypothesis and the issuance of incorrect pricing theory is in securities issuance which predicts the reduction in future stock returns in both hypotheses. The distinguishing feature between these two hypotheses is debt issuance. Incorrect pricing hypothesis predicts decreasing future stock market returns while wealth transfer hypothesis predicts the increase of shareholders' wealth through issuing long-term debt. The results of this study were consistent with the theory of incorrect pricing. As debt issuance decreases, the return on equity also reduces and therefore the wealth transfer hypothesis was not confirmed. Fathi (1999) investigated the effect of financing methods on the value of the companies. He concluded that the percentage changes in companies' stock prices with high debt ratios is less than companies with low of debt ratios. Bradshaw, Richardson, and Sloan (2006) investigated the relationship between corporate financing activities through surveying the literature on stock returns during 30 year period and concluded that there was an inverse relationship between the net cash flows relating to investing or financing activities of each of the classes (issuance of stock) and the stock returns as well as corporate profitability. Innovation of research projects referred to the use of cash flow statement for financing data and did not take into account other forms of changes in capital structure such as increase in capital from receivables, retained earnings, and reserves, and debt conversion into the capital. They examined the two hypotheses of incorrect pricing and transfer of wealth at the same time.

McLaughlin, Safieddine, and Vasudevan (1996) reviewed long-term operational performance of 960 offerings of non-convertible debt and 1967 seasoned equity offerings (SEO) from 1980 to 1993. To assess operational performance, they used measures such as Cash Flow from Operations on Assets (CFOA) and Cash Flow from Operations on Sales 
(CFOS). In this study, the measures of operational performance related to three years before SEO was compared with performance measures of stocks from three years after it. The results showed a significant improvement in their operational performance which reduces about 20 per cent during three years after SEO. Also, the greatest reduction in operational performance was observed through the issuance of stocks. The companies which had a greater increase in performance before the stock issuance, faced with more decrease in their performance following the issuance of stock. The results were consistent with the free cash flow theory, because decrease in performance was greater for companies that had earned additional free cash flow. Hertzel, Lemmon, Linck, and Rees (2002) studied the long-term performance of New York stock exchange market that attempted to offer private placement of stocks. To measure the operational performance of the private placement of stocks, they used three measures including return of assets, operating income before depreciation plus interest on assets (OIBDA), and operating profit divided by the assets. The results showed that despite stock market value rising at the time of offering, companies which offered stocks in private, over a period of three years following the issuance, achieved better performance compared to pre-release period; although, the performance of these companies was lower than average industry performance. Heron and Lee (2004) evaluated the effect of different methods of issuing stocks such as Initial Public Offerings (IPO), secondary offerings, and supply the priority purchase of shares on their operational performance. They found that companies which regularly offer stocks in their initial offering experienced improvements in their operational performance. Generally, this study indicated that operational performance is largely associated with the type of financing in the companies.

\section{Overinvestment of Free Cash Flows Hypothesis}

In this theory, it is believed that the managers of companies have more information on the value of companies' assets and new investment opportunities compared to the stock market. This confidential information transferred into the capital market knowingly or unknowingly through various ways including the issuance of new securities. Mayer and Majluf (1984) argued that the managers with important confidential information are more motivated to issue the securities at a price higher than the intrinsic value. Therefore, the investors understand that released securities have evaluated expensive. This hypothesis in its simplest form predicts that a rapid decline in prices occurs at the time of issuing new shares. When the stock price becomes larger than the nominal price, overinvestment of free cash flows increases and as a consequence its price decreases at the time of issuance. According to this theory, the negative reaction to the issuance of stock market is more for companies with low growth (companies with large assets but limited investment opportunities) and is less for highgrowth companies with limited assets but high investment opportunities (Kabir \& Roosenboom, 2003).

\section{Operation Income before Depreciation plus Interest on Sales (OIBDS)}

This hypothesis states that the companies' managers prefer to increase their assets, even if it decreases the value of company. In other words, they prefer to spend free cash flow more for expanding their interests instead of dividing among shareholders. Securities issuance 
increases the company's free cash flow, encounters the shareholders with higher agency costs, and reduces share price. This hypothesis also predicts that stock returns and operational performance have a significant relationship with ratio of market value of assets to their book value. Thus, stock returns and operational performance may reduce by decreasing the stock price after securities issuance. According to Modigliani and Miller (1958), financing and company's capital structure had no significant effect on the value of the firm due to the arbitrage process.

Myer (1989) studied and compared the financial structures of various industrial companies in eight countries from 1985 to 1970 . The results revealed that the retained earnings are the main sources of financing in all countries, especially in England, Canada, and America and in America and the UK more than 75 per cent of the capitals are achieved through retained earnings of financing. There is an inverse relationship between the use of retained earnings and bank credit. Furthermore, small and medium companies compared with large enterprises use more foreign outsources and are more related to the commercial banks in financing and use less securities for financing (Mayer, 1988, 1989, 1990).

Corbett and Jenkinson (1994) examined financing methods of developed countries for the years 1989-1970. Their study revealed that the most important financing method in all companies' of studied countries is internal resources. Furthermore, issuance of securities and bonds are a small part of financial resources in countries being reviewed. Another most important source of external financing is mortgage loans by banks to the studied companies. They also understood that the internal sources of financing in America and England are more important than Japan. Demirguc-Kunt and Maksimovic (1996) have carried out in the field of finance and corporate capital structure theory. Momeni and Najafi Moghadam (2004) examined the economic performance of listed companies on Tehran stock exchange market by using TOPSIS model.

\section{Evaluation of Factors Affecting the Financing}

Common framework for analyzing different financing methods is usually based on factors such as flexibility, risk, profit, timing, control, and other factors such as collateral value, the cost of securities, and pace and future consequences. Operating flexibility refers to the impacts of current financing decisions on returns in future periods. Risk and return are closely connected and are of great importance. Also, shareholders are interested in controlling profitable unit of business. If a small number of shareholders are the owners of the majority stoke of a profit unit of business and control the mentioned unit, the maintainace of this control in making decisions, selecting the best methods of financing, and the impact of each of these methods on the value of the company will attract special attention. In large corporations that have several shareholders, the control factor does not have significant impact on financial decisions. Timing is also considered to be a very important factor in analyzing the method of financing. The importance of these factors depends on the volatility of the stock markets and bonds. It means that large amount of volatility increases the importance of timing. Other factors that should be taken into account are collateral values, flotation cost, speed, and exposure. Collateral values refers to the available assets which can be used as secure for a loan while flotation cost refers to the expenses for issuing and selling 
of securities. Speed shows how fast the required funds can be raised and be available. Finally, the future exposure represents the maximum future opportunities which are achieved through issuing the securities and acquainting the buyers with profit unit of business.

\section{Research Questions}

In line with the discussion above, the following research questions were formulated:

- Which one more used by venture companies listed in the Tehran Stock Exchange Market for the financing, internal resources or issuance of common stock?

- Is there any significant relationship between firm size and common stock financing?

- Is there any significant relationship between fixed assets of surveyed companies and common stock financing?

- Is there any significant relationship between profitability capacity of studied companies and common stock financing?

- Is there any significant relationship between the future stock returns and financing through issuing common stock?

\section{Method}

The statistical population of the study consisted of all active companies listed on the Tehran Stock Exchange from 2008 to 2013 which were initially selected using random sampling. These companies were selected from six industrial areas including equipment industry, food industry, chemical industry, non-metallic products, and automobiles and heavy metals and then venture companies were identified. Using stratified random sampling, each industry as a class was selected and then by applying the Cochran formula the sample size $(n=40)$ was determined. The sample of study were selected based on criteria such as availability of information for all studied years, ending the company's fiscal year in March, not having trading interruption for more than six months, and not relating to financial intermediation.

This study was carried out through a survey method using a researcher-made questionnaire as the main instrument. In order to collect the data and to test the hypotheses of the study, researcher-made questionnaires consist of 37 questions were distributed among the samples. To confirm the validity, face and content validity were used. For this purpose, the researchers asked five management experts in the field to rate the instrument's efficacy. Informants were instructed to rate themselves using a five point Likert-scale rating from highly satisfied to highly dissatisfied. Based on the data gathered, the reliability coefficient alphas were calculated through Cronbach's alpha to be 0.96. Initially, as a pilot study, 30 questionnaires were distributed among the population and then based on the obtained results; the vague questions were modified and deleted to deliver the final form of a questionnaire.

To analyze the data, both descriptive and inferential statistical methods were used. Descriptive statistics was used for studying the characteristics and features of data collection and inferential statistics was used to analyze the questionnaire through applying SPSS software. Also, data of venture companies listed on the Tehran Stock Exchange were collected using the information retrieved from the website of the Tehran Stock Exchange and 
Tadbir Pardaz IT group as well as publications annual reports, and other audited financial statements.

\section{Results}

Table 1 presents the statistical analysis of the data collected related to the first research question. Except in 2011, $t$-values of other years indicate that there was not any significant difference between financing through retained earnings and stock.

Table 1

Comparison between Financing through Retained Earnings \& Stocks

\begin{tabular}{|c|c|c|c|c|c|c|}
\hline Years & Description & Average & NO. & T-Statistics & Error Probability & Conclusion \\
\hline \multirow{2}{*}{2008} & Retained Earnings & 8718.4 & 40 & 0.83 & 0.40 & The difference was not significant \\
\hline & Stocks & 42643.8 & 40 & & & \\
\hline \multirow[b]{2}{*}{2009} & Retained Earnings & 8718.4 & 40 & 0.76 & 0.44 & The difference was not significant \\
\hline & Stocks & 14683.2 & 40 & & & \\
\hline \multirow[b]{2}{*}{2010} & Retained Earnings & 19827.7 & 40 & 0.39 & 0.69 & The difference was not significant \\
\hline & Stocks & 22591.1 & 40 & & & \\
\hline \multirow[b]{2}{*}{2011} & Retained Earnings & 13523.8 & 35 & -0.00 & 0.99 & The difference was not significant \\
\hline & Stocks & 13504.1 & & & & \\
\hline \multirow[t]{2}{*}{2012} & Retained Earnings & 3868.02 & 40 & 2.17 & 0.02 & The difference was not significant \\
\hline & Stocks & 50112.5 & & & & \\
\hline \multirow{2}{*}{2013} & Retained Earnings & 18869.02 & 40 & 1.66 & 0.10 & The difference was not significant \\
\hline & Stocks & 49614.1 & & & & \\
\hline
\end{tabular}

According to Table 2, there is a significant relationship between company size and financing through stocks issuance from 2008- 2013. Only in 2010, there is no significant relationship between these two variables. Moreover, there is a positive significant relationship between the fixed assets and equity financing in all years. Table 2 indicates that there is also a significant relationship between profitability capacity and financing through stocks issuance. Finally, the negative amount of Pearson correlation coefficient (-0.045) indicates that the relationship between the future stock returns and financing through stocks issuance and stocks in a given period of time is not significant. This result is also confirmed with Spearman coefficient, with the amount of -0.029 and the error level of 0.05 . As a result, we are 95 per cent confident that there is no significant relationship between the future stock returns and financing through the stock issuance. 
Table 2

The Relationship between Company Size, Fixed Assets, Profitability Capacity, \& Future Stock Returns \& Financing through Stocks Issuance

\begin{tabular}{|c|c|c|c|c|}
\hline & Years & Error Probability & Correlation Coefficient & Results \\
\hline \multirow{6}{*}{$\begin{array}{l}\text { Relationship between Company } \\
\text { Size \& Financing through } \\
\text { Stocks Issuance }\end{array}$} & 2008 & 0 & 0.83 & There is a significant relationship \\
\hline & 2009 & 0.02 & 0.30 & There is a significant relationship \\
\hline & 2010 & 0 & 0.59 & There is a significant relationship \\
\hline & 2011 & 0.42 & 0.12 & There is a significant relationship \\
\hline & 2012 & 0 & 0.84 & There is a significant relationship \\
\hline & 2013 & 0.04 & 0.28 & There is a significant relationship \\
\hline \multirow{6}{*}{$\begin{array}{l}\text { Relationship between Fixed } \\
\text { Assets and Financing through } \\
\text { Stocks Issuance }\end{array}$} & 2008 & 0.00 & 0.89 & There is a significant relationship \\
\hline & 2009 & 0.02 & 0.32 & There is a significant relationship \\
\hline & 2010 & 0.03 & 0.30 & There is a significant relationship \\
\hline & 2011 & 0.65 & -0.06 & There is a significant relationship \\
\hline & 2012 & 0.50 & 0.09 & There is a significant relationship \\
\hline & 2013 & 0.00 & 0.53 & There is a significant relationship \\
\hline \multirow{6}{*}{$\begin{array}{c}\text { Relationship between } \\
\text { Profitability Capacity and } \\
\text { Financing through Stocks } \\
\text { Issuance }\end{array}$} & 2008 & 0.00 & 0.89 & There is a significant relationship \\
\hline & 2009 & -0.20 & 0.14 & There is a significant relationship \\
\hline & 2010 & 0.05 & 0.68 & There is a significant relationship \\
\hline & 2011 & 0.08 & 0.60 & There is a significant relationship \\
\hline & 2012 & 0.02 & 0.86 & There is a significant relationship \\
\hline & 2013 & 0.07 & 0.63 & There is a significant relationship \\
\hline \multirow{6}{*}{$\begin{array}{l}\text { Relationship between Future } \\
\text { Stock Returns and Financing } \\
\text { through Stocks Issuance }\end{array}$} & 2008 & & & There is not a significant relationship \\
\hline & 2009 & & & There is not a significant relationship \\
\hline & 2010 & & & There is not a significant relationship \\
\hline & 2011 & & & There is not a significant relationship \\
\hline & 2012 & & & There is not a significant relationship \\
\hline & 2013 & & & There is not a significant relationship \\
\hline
\end{tabular}

\section{Discussion and Conclusion}

This paper tried to investigate the issuance of stocks as one of external financing methods in venture companies listed in the Tehran Stock Exchange and its relationship with company size, fixed assets, profitability capacity, and future stock returns has been investigated. The results of study revealed that there was no significant difference between financing through using internal financial resources and the issuance of stocks. It can be said that due to being fledgling of new listed companies in Tehran Stock Exchange Market, there has been no significant desire in country to save the profit. New listed companies on the Stock Exchange Market have tended to improve the distribution of profits in the early years of being accepted. They announced to their shareholders that the company has been involved in the profitability and distribution of the profits among shareholders. In the capital markets with semi-strong performance, lack of good distribution of profits has not been always considered as a failure and participants in the markets have been aware of the accumulated profits due to good investment opportunities in the future. Furthermore, there is a significant relationship between company size and financing through stocks issuance. The larger older companies tend to adjust the capital structure to achieve optimal financing structure which results into 
the financing through issuance of common stocks (internal common stock and new common stock). Also, there is a significant relationship between issuance of stock and fixed assets. For acquiring of required fixed assets, companies often use the financing methods through issuing the stocks. The findings also indicated that there is a significant relationship between financing through stocks issuance and profitability. It means that companies have been indifferent to method of financing through the issuance of stocks in any position of profitability. In a separate study, the existence of optimal capital structure of studied companies can be investigated and in case of being positive, a justification for the lack of correlation between profitability and financing through the stocks issuance is delivered. Finally, there is a no significant relationship between financing through the issuance of stocks and future stock returns. The results of this study are consistent with previous studies which were presented in the review of literature. It means that the surveyed companies provide no changes in the cash returns and prices for their owners. This study suggested that big companies with higher capital intensity for providing their required liquidity can use the methods of retained earnings and issuing new stocks. Companies should emphasize more on issuing new stocks than debt methods for providing the necessary liquidity to purchase their required fixed assets.

\section{References}

Adel, A., \& Momeni, M. (1999). Statistics and its application in management (15th ed.). Tehran: Samt Publication.

Bigdelo, M. (2004). Investigation on the entrepreneurship financing. Tehran: University of Tehran Press.

Bradshaw, M. T., Richardson, S. A., \& Sloan, R. G. (2006). The relation between corporate financing activities, analysts' forecasts, and stock returns. Journal of Accounting Economics, 42, 53-85.

Casser, G. J. (2005). External financing and firm operating performance (Unpublished doctoral dissertation). University of California, Berkeley.

Corbett, J., \& Jenkinson, T. (1994). The financing of industry, 1970-89: An international comparison. London: Center of Economic Policy Research.

Demirguc-Kunt, A. \& Maksimovic, V. (1996). Stock market developing and financing choice of firms. World Bank Economic Review, 10(2), 34-371.

Eberhart, A. C., \& Siddique, A. (2002). The long-term performance of corporate bonds (and stocks) following seasoned equity offering. Review of Financial Studies, 15(5), 1385-1406.

Fathi, M. (1999). The effect of financing on the value of listed companies on the stock exchange (Unpublished master's thesis). Shahid Beheshti University, Tehran.

Healy, P. M., \& Krishna, G. P. (1990). Earning and risk changes surrounding primary stock offers. Journal of Accounting Research, 28(1), 25-48.

Hertzel, M., Lemmon, M., Linck, J., \& Rees, L. (2002). Long-run performance following private placements of equity. Journal of Finance, 57(6), 2595-2617.

Heron, R., \& Lee, E. (2004). A comparison of the motivation for and the information content of different types of equity offering. Journal of Business, 77,605-632.

Hillier, D., Ross, A., Westerfield, R., Jaffe, J., \& Jordan, B. (1991).Corporate finances (3rd ed.). New York: McGraw-Hill Companies.

Kabir, R., \& Roosenboom, P. (2003). Can the stock market anticipate future operating performance? Evidence from equity rights issues. Journal of Corporate Finance, 9(1), 93-113.

Loughran, T., \& Ritter, J. (2000). Uniformly least powerful tests of market efficiency. Journal of Financial Economics, 55(3), 361-389.

Mayers, S. C. (1984). The capital structure puzzle. Journal of Finance, 39(1), 581-582. 
Mayer, S. C., \& Majluf, N. (1984). Corporate financing and investment decisions when firms have information that investors do not have. Journal of Financial Economics, 13, 187-221.

Mayer, C. (1988). New issues in corporate finance. European Economic Review, 32(5), 1167-1189.

Mayer, C. (1989). Myths of the West: Lessons from developed countries for development finance. Washington, D. C.: World Bank.

Mayer, C. (1990). Financial systems, corporate, and economic development. In G. Hubbard (Eds.), Asymmetric information, corporate finance, and investment Chicago: University of Chicago Press.

McLaughlin, R., Safieddine, A., \& Vasudevan, G. K. (1996). The operating performance of seasoned equity issuers: Free cash flow and post- issue performance. Financial Management, 25(4), 41-53.

Modigliani, F., \& Miller, M. (1958). The cost of capital, corporation finance, and the theory of investment. American Economical Review, 48(3), 261-297.

Momeni, M., \& Najafi Moghadam, A. (2004). Evaluating the economic performance of listed companies on the Tehran Stock Exchange by using TOPSIS. Economic Review Quarterly, 1(3), 75-55.

Rezaul, K., \& Roosenboom, P. (2003). Can the stock market anticipate future operating performance? Evidence from equity rights issues. Journal of Corporate Finance, 9(1), 93-113.

Shabahang, R. (2005). Financial management. Tehran: Auditing Organization Publication.

Van Horne, J. (1992). Financial management (M. Dastgir, Trans.).Tehran: Academic Books Publication.

Van Horn, J., \& Wachowicz, J. M. (1995). Fundamentals of financial management (13th ed.). Englewood Cliffs, NJ: Practice Hall. 